\title{
Effectiveness of ambon banana stem juice as immunostimulatory against Aeromonas hydrophila infections in catfish Clarias gariepinus
}

\author{
Efektivitas air perasan batang pisang ambon sebagai imunostimulan \\ terhadap infeksi Aeromonas hydrophila pada ikan lele Clarias gariepinus
}

\author{
Qorie Astria, Sri Nuryati*, Kukuh Nirmala, Alimuddin Alimuddin \\ Department of Aquaculture, Faculty of Fisheries and Marine Science, Bogor Agricultural University \\ Campus IPB Dramaga Bogor, West Java, Indonesia 16680 \\ *E-mail: sri.nuryati606@gmail.com
}

\begin{abstract}
Outbreaks of infectious diseases due to Aeromonas hydrophila in catfish can cause high death rates (80-100\%). Fish disease control can be done using phytopharmaceutical to prevent or treat diseases of fish. One of the phytopharmaceutical that known to prevent the fish diseases is ambon banana stem Musa cavendishii var. dwarf Paxton. This study was conducted to test the effectiveness of catfish immersion using banana stem juice as an immunostimulant against bacterial infections A. hydrophila. The observed parameters were a total performance of production, hematological test, and water quality. Immersion of catfish seeds with stem juice was performed at a concentration of $5 \mathrm{~mL} / \mathrm{L}, 13 \mathrm{~mL} / \mathrm{L}$, and $21 \mathrm{~mL} / \mathrm{L}$ for 30 minutes. Each treatment consisted of three replications. A total of 15 fishes were immersed in $1.5 \mathrm{~L}$ water. At day- 9 after immersion, fish was infected by $A$. hydrophila bacteria at a dose of $10^{4} \mathrm{cfu} / \mathrm{mL}$. The results showed that fish treated with banana stem juice at a concentration of $13 \mathrm{~mL} / \mathrm{L}$ had the survival rate of $53.33 \pm 6.67 \%$ which is higher than positive control $(33.33 \pm 6.67 \%)$. Based on hematology observations on the 3rd day post-challenge test (H12) with A. hydrophila, total erythrocytes, hemoglobin, total leukocytes, phagocytic activity, differential leukocyte, and lysozyme activity was highest in treatment $13 \mathrm{~mL} / \mathrm{L}$. Lower feed conversion ratio $(1.08 \pm 0.04)$ were also obtained in treatment $13 \mathrm{~mL} / \mathrm{L}$. Thus Immersion of seeds in stem juice can boost the immune system against infections A. hydrophila.
\end{abstract}

Keywords: Aeromonas hydrophila, ambon banana stem juice, soaking, catfish, immune system

\begin{abstract}
ABSTRAK
Wabah penyakit akibat infeksi Aeromonas hydrophila pada ikan lele dapat menyebabkan tingkat kematian yang tinggi (80-100\%). Penanggulangan penyakit ikan dapat dilakukan menggunakan fitofarmaka untuk mencegah ataupun mengobati penyakit ikan. Salah satu fitofarmaka yang dapat digunakan dalam upaya pencegahan penyakit ikan adalah batang pisang ambon lumut Musa cavendishii var. dwarf Paxton. Penelitian ini bertujuan untuk menguji efektivitas perendaman benih ikan lele dengan menggunakan air perasan batang pisang ambon sebagai imunostimulan terhadap infeksi bakteri A. hydrophila. Parameter yang diamati selama penelitian adalah kinerja produksi, uji hematologi dan pengukuran kualitas air. Perendaman benih ikan lele dengan air perasan dilakukan pada konsentrasi $5 \mathrm{~mL} / \mathrm{L}, 13 \mathrm{~mL} / \mathrm{L}$, dan $21 \mathrm{~mL} / \mathrm{L}$ selama 30 menit. Pada hari ke-9 setelah perendaman, ikan diinfeksi bakteri A. hydrophila pada kepadatan $10^{4} \mathrm{cfu} / \mathrm{mL}$. Hasil penelitian menunjukkan bahwa perendaman ikan dengan air perasan pada konsentrasi $13 \mathrm{~mL} / \mathrm{L}$ memiliki kelangsungan hidup yakni sebesar 53,33 $\pm 6,67 \%$, lebih tinggi bila dibandingkan dengan kontrol positif $(33,33 \pm 6,67 \%)$. Berdasarkan pengamatan pada uji hematologi hari ke-3 pascauji tantang (H12) dengan bakteri A. hydrophila, total eritrosit, hemoglobin, total leukosit, aktivitas fagositik, dan aktivitas lisozim tertinggi terdapat pada perlakuan konsentrasi $13 \mathrm{~mL} / \mathrm{L}$. Rasio konversi pakan yang rendah $(1,08 \pm 0,04)$ juga terdapat pada perlakuan $13 \mathrm{~mL} / \mathrm{L}$. Hal ini menunjukkan bahwa perendaman benih ikan lele pada air perasan dapat meningkatkan sistem imun terhadap infeksi bakteri A. hydrophila.
\end{abstract}

Kata kunci: Aeromonas hydrophila, air perasan batang pisang ambon, perendaman, ikan lele, sistem imun 


\section{INTRODUCTION}

The African catfish Clarias gariepinus, especially the sangkuriang strain, is a commodity in aquaculture commodity with high economic value and well appreciated by communities in Indonesia. A cause of failure, however, in mass catfish production is a disease caused by a bacterium called Aeromonas hydrophila, which can engender mass death. According to Lukistyowati and Kurniasih (2011), the mentioned bacterium can give rise to high mortality (80$100 \%$ ) within $1-2$ weeks.

Preventing A. hydrophila outbreak is quite difficult since it has various strains and is always present in the water body. A countermeasure against fish diseases is the use of antibiotics or chemical substances, which, however, can have negative impacts on the environment (pollution) (Rairakhwada et al., 2007). In addition, the accumulation of antibiotics residue can affect growth, and result in a resistance of bacteria against drugs as well as immunosuppression (Maqsood et al., 2009).

An effort that can be carried out to avoid the use of antibiotics in overcoming fish disease is by taking advantage of phytopharmaceutical products to prevent or treat diseases, and a phytopharmaceutical product that can be used in that way is ambon banana stem moss Musa cavendishii var. dwarf Paxton. Banana is a plant that grows in tropical areas and bears fruit just once in its life cycle so that it could become waste if not utilized. It consists of root, stem, and leaf that contain a few active immunostimulant and anti-inflammatory compounds. Among all the parts of the mentioned banana tree, the stem has the highest active immunostimulant compound (Loganayaki et al., 2010).

The stem of ambon banana is a waste, which possesses health properties but is not properly utilized (Prasetyo et al. 2010). The effectiveness of immersing catfish, that have been infected by A. hydrophila bacteria, in ambon banana stem extract has been evaluated in previous research. It has been proved that the immersion of catfish in ambon banana stem extract could increase the survival rate up to $83.33 \%$ (Lidiawati, 2014). Phytochemical analysis results from the center for plant spices and drugs research revealed that banana stem juice contains saponin, flavonoids, and tannin. In fact, the flavonoid is an active compound that can be used as antioxidant, antibacteria, anti-inflammatory, and anti-fungi.
The use of immuno-stimulant from phytopharmaceutical product has been widely applied by researcher through both immersion and oral (feed). Based on a research conducted by Lidiawati (2014), the use of ambon banana stem, which was processed into powder to facilitate its absorption, resulted in an application method that was not effective enough for the large scale farming system. Thus, there is a need to develop a more practical/economic method in preventing motile aeromonad septicemia (MAS) infection that attacks juvenile catfish, through immersion using squeezed ambon banana stem juice.

The present research was aimed to evaluate the effectiveness of immersing catfish Clarias gariepinus juvenile (sangkuriang strain) in squeezed ambon banana $M$. cavendishii var. dwarf Paxton stem juice, as the immunostimulant, against $A$. hydrophila bacterial infection.

\section{MATERIALS AND METHODS}

\section{Research design}

The presentresearch evaluated the effectiveness of using squeezed ambon banana stem juice as immunostimulant in juvenile catfish and used a complete randomized design, which consisted of five treatments (three replicates each) as follows: two immersion treaments without squeezed ambon banana stem juice i.e. (K-) and (K+) and three immersion treaments using squeezed ambon banana stem juice at different doses i.e. $5 \mathrm{~mL} / \mathrm{L}$ (treatment A), $13 \mathrm{~mL} / \mathrm{L}$ (treatment $\mathrm{B}$ ), and 21 $\mathrm{mL} / \mathrm{L}$ (treatment $\mathrm{C}$ ).

Immersion was performed by collecting the fish from a test aquarium and placing them in diferent caontainers, that were previously filled with $1.5 \mathrm{~L}$ of squeezed ambon banana stem juice for 30 minutes. After the 30 minutes immersion time, the fish were placed back into test aquariums. The immersion process was repeated 7 times in a week (in the morning, just before feeding).

\section{Ambon banana stem juice preparation}

Ambon banana stem used in the present research was brought from Pabuaran village, Ciampea sub-district, Bogor District. The stem juice was obtained by cutting the whole stem, that was harvested at the age of \pm 5 months, and squizzing it by mean of a squizzing machine without adding water. Afterwards, the squeezed banana stem juice was filtered using filter paper (Whatman 41) with a size of $20-25 \mu \mathrm{m}$ pores in order to separate the dregs (from the stem) and 
the juice, which composition was quantitatively analysed at the center for plant spices and drugs in Bogor. Analysis results revealed that ambon banana stem juice contained saponin $(0.22 \%)$, tannin $(0.011 \%)$, and flavonoids $(2.02 \%)$.

\section{Container preparation and fish rearing}

Aquariums with a size of $65 \times 30 \times 35 \mathrm{~cm}^{3}$ were used in the present study and filled with water up to a height of $25 \mathrm{~cm}$ and equipped with aeration stones. Water exchange was performed every 3 days, $30-50 \%$ of the water volume, in the morning just before feeding.

Juvenile catfish (Sangkuriang strain) at an average size of $5-7 \mathrm{~cm}$ were brought from Babakan village, Bambu Kuning village, Pamijahan district. Fish were acclimatized in aquariums for 7 days. Initial body weight and length were collected, prior to stocking and fish were stocked at a density of 15 fish/aquarium. The rearing period lasted for 23 days and feeding was performed twice a day, at satiation, using commercial feed (39-41\% protein).

\section{Bacteria and challenge test}

A. hydrophila bacteria was brought from the fish research and development installation for disease control, Depok. The bacterium was intramuscularly injected in the fish to evaluate its virulence. The mentioned bacterium was isolated and cultured on TSB (Trypticase Soy Broth) medium for 24 hours prior to injection at a dose of $0.1 \mathrm{~mL} / \mathrm{fish}$. A. hydrophila bacteria re-isolation was performed from various parts of the fish body such as ulcers, liver, and kidneys, once the fish displayed clinical symptoms of $A$. hydrophila infection. Re-isolation was carried out on RS (Rimmler Shotts) and incubated at $37{ }^{\circ} \mathrm{C}$ for 24 hours to obtain a virulent $A$. hydrophila bacterium.

Bacteria were re-characterized using both physiological and biochemical tests by mean of conventional methods and API 20E kits. The biochemical observation was carried out via gram staining, oxidative/fermentative test, motility test, catalase test, oxidase test, and gelatin test. The dose of bacteria used in the challenge test was determined through $\mathrm{LD}_{50}$ test. It was confirmed, based on biochemical and API 20E test results, that the mentioned bacterium was A. hydrophila. Challenge test was carried out on day 9 postimmersion (7 times a week) by injecting $A$. hydrophila at a concentration of $10^{4} \mathrm{cfu} / \mathrm{mL}$ and a dose of $0.1 \mathrm{~mL} /$ fish. Dead fish were weighed.

\section{Blood samples collection}

Blood samples were collected from blood vessels on the vena caudal and the fish used in the hematology test were sampled from replicate groups that were different to the production performance test. The procedure used in collecting blood samples involved anesthetizing fish using ocean free special arowana tabilizer at a concentration of $1 \mathrm{~mL} / \mathrm{L}$. Afterward, a syringe, previously rinsed with anti-anticoagulant, was inserted in the center line of the fish body (behind the anal fin) and the needle was inserted in the mucus up to the backbone (Columna spinalis). Then, it was assured that no water bubbles entered before pulling step by step until the blood entered the syringe. The blood collected from 4 fish was placed into microtubes previously rinsed with anti-anticoagulant.

\section{Production performance parameters}

Production performance parameters involved survival rate that was observed for 23 days during test fish rearing period, absolute growth rate (observed up to day 8 before challenge test), feed consumption and feed conversion ratio (performed at the end of the challenge test).

\section{Survival rate}

Fish survival rate was observed from the beginning until the end of the rearing period and was determined using the following formula:

$$
\mathrm{SR}=\mathrm{Nt} / \mathrm{No} \times 100
$$

Note:

$\mathrm{SR}=\operatorname{survival}(\%)$

$\mathrm{Nt}=$ the number of the alive fish at the final observation (individuals)

No $=$ the number of the alive fish at the initial observation (individuals)

\section{Absolute growth rate}

The absolute growth rate was determined using the following formula:

$$
\mathrm{W}=\mathrm{Wt}-\mathrm{Wo}
$$

Note:

$\mathrm{W}=$ absolute growth rate

Wo $=$ fish total weight at the initial of rearing (g)

$\mathrm{Wt}=$ fish total weight at the end of rearing $(\mathrm{g})$ 


\section{Feed conversion ratio}

Feed conversion ratio was determined using the following formula:

$$
\mathrm{FCR}=\mathrm{F} /[(\mathrm{Wt}+\mathrm{D})-\mathrm{Wo}] \times 100
$$

Note:

$\mathrm{Wt}=$ the average weight of the fish at the end of the study (g)

Wo $=$ the average weigth of the fish at the beginning of the study $\mathrm{T}_{1}(\mathrm{~g})$

$\mathrm{F} \quad=$ total of feed given during rearing period (g)

$\mathrm{D}=$ biomass of dead fish $(\mathrm{g})$

\section{Clinical symptoms observation}

The observation of clinical symptoms involved behavior i.e. responsiveness to feed, movement reflexes, and abnormalities. These parameters were observed daily for a period of 14 days after infecting the fish with A. hydrophila bacterium.

\section{Hematology parameters}

Hematological parameters that were observed in the present study consisted of total erythrocytes, hemoglobin, total leukocytes, phagocytic activities, and lysozyme activity, which were observed prior to treatments (D0), 8 days posttreatment (D8), 3 days post-challenge test (D12), 8 days post challenge test (D17), and at the end of the research (D23). Clinical symptoms were daily observed for 14 days post-challenge test with $A$. hydrophila.

\section{Total erythrocytes}

Fish blood samples were sucked by mean of a pipette that was previously filled with red stirrer up to 0.5. Afterward, Hayem's solution was added up to a scale of 101 , and the mixture was then stirred by shaking the pipette (to form an 8 shape) for 3-5 minutes until the blood was evenly mixed. The first 2 drops of the obtained solution were disposed and the solution was then dropped on a hemocytometer, on which a covering glass was placed. Total erythrocytes were determined based on the following formula:

\section{EErythrocytes $\left(\right.$ cell $\left./ \mathrm{mm}^{3}\right)=$} counted cell $\times$ dilution factor box volume

\section{Hemoglobin level}

Hemoglobin level was measured based on Sahli method i.e. by filling haemometer with $\mathrm{HCl}$
$0.1 \mathrm{~N}$ solution up to the red line that represents the scale of 10 and then placing it between two standard colored tubes. Fish blood in the microtube was collected using a Sahli pipette, about 0.02 $\mathrm{mL}$, and placed in a Sahli tube for a period of 3 minutes. Afterward, distilled water was gradually added using the pipette and mixed until a change in color occurred (same as the standard color). Hemoglobin level was determined in $\mathrm{g} / \mathrm{dL}$ on a yellow scale.

\section{Total leukocytes}

The blood sample of fish was sucked by mean of a pipette that was previously filled with white stirrer up to 0.5. Afterward, Turk's solution was added up to a scale of 11 and shook in a way to form an 8 shape for 3-5 minutes until the blood was evenly mixed. The first 2 drops of the obtained solution were disposed and the solution was then dropped on a hemocytometer, on which a covering glass was placed. The solution will capillary meet the counting chamber and leukocyte was determined based on the following formula:

\section{$\sum$ Leukocytes $\left(\right.$ cell $\left./ \mathrm{mm}^{3}\right)=$ counted cell $\times$ dilution factor box volume}

\section{Phagocytic activity observation}

Phagocytic activity was determined by collecting $50 \mu \mathrm{L}$ of blood and placing it into a microtube and added with $50 \mu \mathrm{L}$ Staphylococcus aureus suspension in PBS $\left(10^{7}\right.$ cell $\left./ \mathrm{mL}\right)$. The solution was then homogenized and incubated at room temperature for 20 minutes. A pillowcase was made and dried (air). Afterward, the pillowcase was immersed in methanol solution for 5 minutes, dried, stained (by immersion in Giemsa stain for 15 minutes), cleaned with running water and finally dried. Afterward, cells undergoing phagocytic activity were observed and counted out of 100 observed phagocytic cells.

Phagocytic activity $(\%)=$

$\sum$ Phagocytizing cell $/ \sum$ Phagocytic cell $\times 100$

\section{Lysozyme activity}

Lysozyme activity was measured by collecting samples $(100 \mu \mathrm{L})$, then added them with Micrococcus lysodeikticus sigma bacterial suspension $(100 \mu \mathrm{L}$ or $0.4 \mathrm{mg} / \mathrm{mL})$ in a $0.1 \mathrm{M}$ Phosphate buffered saline with a $\mathrm{pH}$ of 6.2 , at a temperature of $25{ }^{\circ} \mathrm{C}$. Reading adsorption was performed twice on the wavelength $(450 \mathrm{~nm})$ 
with a microplate reader during 30 seconds, 15 minutes, 30 minutes, 45 minutes, and 60 minutes mixing. Lysozyme activity unit will be limited to some enzymes that cause reductions in absorbent (0.001/minutes). The formula used in determining lysozyme activity is as follows:

Lysozyme activity $(\mathrm{Unit} / \mathrm{mL})=$

(initial OD - final OD) $\times 1000$

time of final measurement

volume of samples

\section{Water quality parameters}

Water quality measurement involved parameters such temperature $\left({ }^{\circ} \mathrm{C}\right), \mathrm{pH}$, dissolved oxygen $(\mathrm{mg} / \mathrm{L})$, Total Ammonia Nitrogen $(\mathrm{mg} / \mathrm{L})$, and ammonia $(\mathrm{mg} / \mathrm{L})$. Temperature and DO were measured by mean of tools such as DO meter and pH-meter. Total ammonia Nitrogen (TAN) was determined in laboratory based on spectrophotometer method, and ammonia level was obtained by converting TAN value.

\section{Data analysis}

Data on parameters such as production performance and hematology test were analyzed using SPSS software (version 16.00). An ANOVA test followed by a Duncan-test if significant differences were observed with an interval of confidence of $95 \%$. Clinical symptoms observations and water quality measurement were descriptively analyzed.

\section{RESULTS AND DISCUSSION}

\section{Results}

Production performance

Data on production performance are presented in Figure 1. Catfish survival rate did not significantly differ $(\mathrm{P}>0.05)$ in treatment $\mathrm{B}$ $(53.33 \pm 6.67 \%)$ and $A(44.44 \pm 3.85 \%)$, which were higher than those of treatments $\mathrm{C}(40 \pm 6.67 \%)$ and $\mathrm{K}+(33.33 \pm 6.67 \%)$. The absolute growth rate that was measured during 8 days prior to the challenge test (Day 9) did not show any significant differences among treatments. However, the highest absolute growth rate was observed in the negative control $(23.26 \pm 1.36 \mathrm{~g})$. The lowest FCR $(\mathrm{P}<0.05)$ was observed in treatment B $(1.08 \pm 0.04)$, while FCR values were similar in ambon banana stem juice treatments.

Total erythrocytes and hemoglobin

Treatment B had the highest erythrocyte level
$(\mathrm{P}<0.05)$ among treatments (Figure 2a) based on the results of the present research on catfish (post-challenge test observation). Erythrocyte levels $\left(1.07 \pm 0.08 \times 10^{6} \mathrm{cell} / \mathrm{mm}^{3}\right)$ were observed to decrease in all treatments on both day 17 and day 23. Similar trends were also noticed on day 12 post-challenge test and the highest hemoglobin level was observed in treatment $\mathrm{B}$, being $7.10 \pm 0.42 \mathrm{~g} / \mathrm{dL}$.

Total leukocytes, phagocytic activity, and lysozyme activity

Total leukocytes observation post-challenge test (D12) showed an increase in treatment B leukocytes level up to $10.7 \times 10^{4} \mathrm{cell} / \mathrm{mm}^{3}$, which was significantly different $(\mathrm{P}<0.05)$ to other treatments except for treatment A $(\mathrm{P}>0.05)$. Phagocytic activities, post challenge test on both D12 and D17, were higher in treatment B, being $47.33 \pm 6.11 \%$ and $47.33 \pm 3.06 \%$, respectively. However, the highest phagocytic activity $(49.33 \pm 4.16 \%)$ was observed in treatment A (on D23), which was not statistically different $(\mathrm{P}>0.05)$ to other treatments except $\mathrm{K}-$ and $\mathrm{K}+$ $(\mathrm{P}<0.05)$. Treatment $\mathrm{B}$ had the highest lysozyme activity on day $12(14.44 \pm 1.02 \mathrm{U} / \mathrm{mL})$, which was significantly different to other treatments. However, lysozyme activity was observed to decrease on D23.

\section{Clinical symptoms}

Clinical symptoms were observed during 14 days post-challenge test with A. hydrophila. Observation results showed clinical symptoms of ulcers (on day 1) in treatment $\mathrm{K}+$ fish, which ulcers, however, decreased over time (day 4) compared to day 1 (Figure 4). On day 9, the ulcers were totally covered and a change in color occurred on the fish body (tending pale). In the ambon banana stem juice treatments (A, B and C), fish experienced fast ulcers recovery compared to treatment $\mathrm{K}+$ i.e. ulcers of most test fish covered on day 7 .

There were also some morphological differences observed such as changes in body color (discoloration), hemorrhage on the fish body, abdominal dropsy, sores or ulcers on injection points (Figure 5). Meanwhile, clinical symptoms of test fish behavior observed post-challenge test with A. hydrophila were: decrease in appetite, irregular movement, and fish swimming at the water surface.

\section{Water quality parameters}

Water quality parameters observed in the 

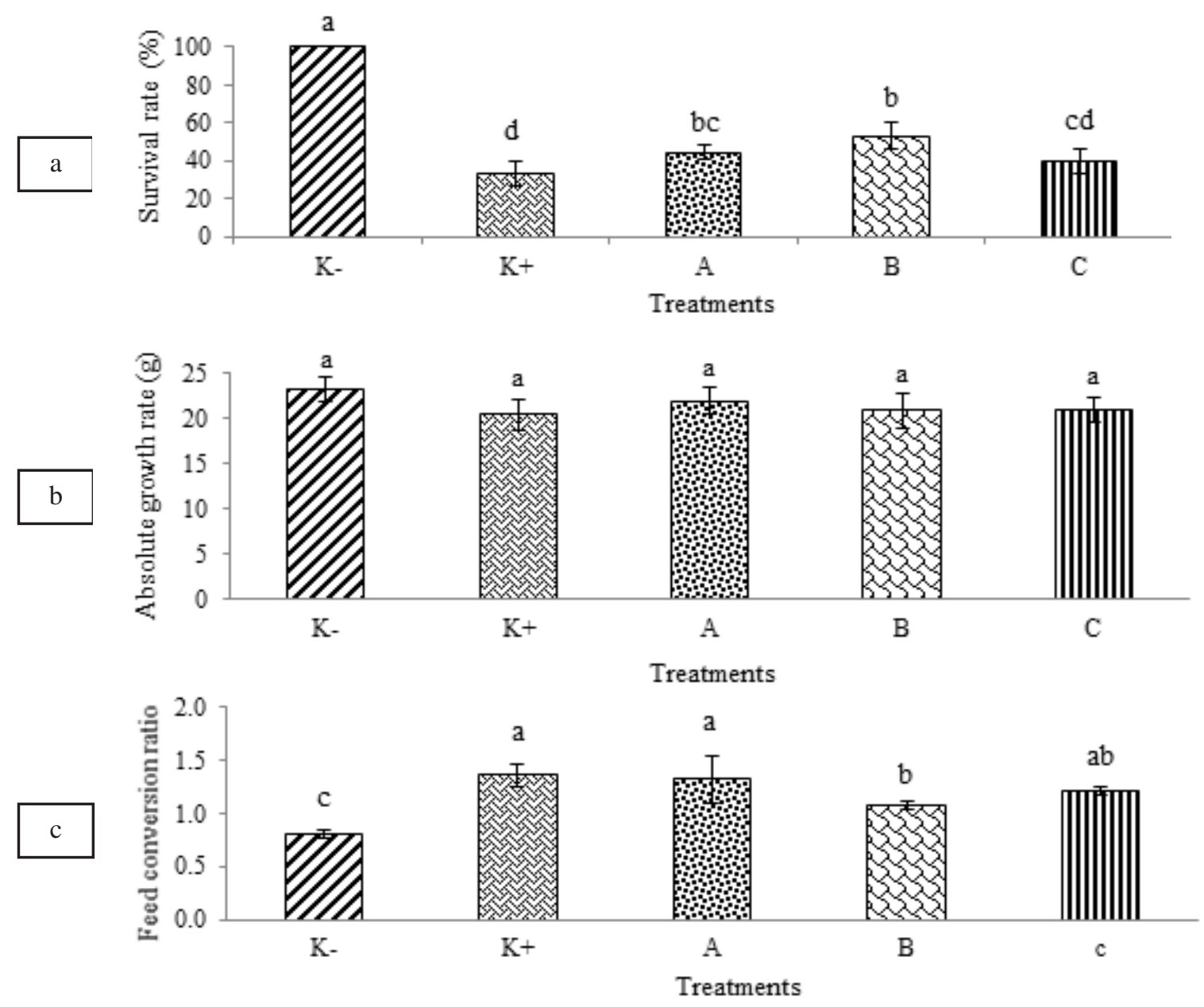

Figure 1. Catfish Clarias gariepinus production performance during the research: (a) survival rate; (b) absolute growth rate; (c) feed conversion ratio. Different letters on each bar showed statistical differences (Duncan's multiple-range test; $\mathrm{P}<0.05)$. Without banana stem juice immersion and challenge test $(\mathrm{K}-)$; challenge test without banana stem juice immersion $(\mathrm{K}+)$; ambon banana stem juice immersion at concentrations of $5 \mathrm{~mL} / \mathrm{L}(\mathrm{A}) ; 13$ $\mathrm{mL} / \mathrm{L}(\mathrm{B}) ; 21 \mathrm{~mL} / \mathrm{L}(\mathrm{C})$ with challenge test.

present study were temperature, $\mathrm{pH}, \mathrm{DO}$, TAN, and ammonia and were measured at both beginning and end of the research. Data on measurement results are presented in Table 2 . According to the Indonesian national standards (2000), the optimum water quality required for fish farming activities are as follows: $25-30{ }^{\circ} \mathrm{C}$ for temperature, 6.5-8.5 for the $\mathrm{pH}$, more than 4 $\mathrm{mg} / \mathrm{L}$ for DO, less than $1 \mathrm{mg} / \mathrm{L}$ for TAN, and less than $0.01 \mathrm{mg} / \mathrm{L}$ for ammonia. In the present study, the water parameters were still within the normal ranges established by the Indonesian national standards (SNI, 2000).

\section{Discussion}

Survival rate can be defined as the living opportunity of an organism at a given period of time. The high survival rate in treatment K- was a consequence of the fish not being subjected to the challenge test, which involved the use of $A$. hydrophila bacteria, leading to health or wellbeing condition of the fish. On the other hand, treatments that were subjected to the challenge test had lower survival compared to treatment $\mathrm{K}$-. Indeed, treatment $\mathrm{B}$ had a survival rate of $53.33 \pm 6.67 \%$, which was significantly different $(\mathrm{P}<0.05)$ compared to treatment $\mathrm{C}(40 \pm 6.67 \%)$, and $\mathrm{K}+(33.33 \pm 6.67 \%)$, but did not dsignificantly to treatment A $(44.44 \pm 3.85 \%)$. The results above proved the influence of saponin, which was contained in ambon banana stem juice, on survival rate. However, the mentioned active compound (saponin) did not affect catfish absolute growth rate. The differences in terms of survival rate in each treatment proved the existence of an optimum concentration of the active compound in ambon banana stem juice. Prasetyo et al. (2010) stated that saponin is a secondary metabolic compound 

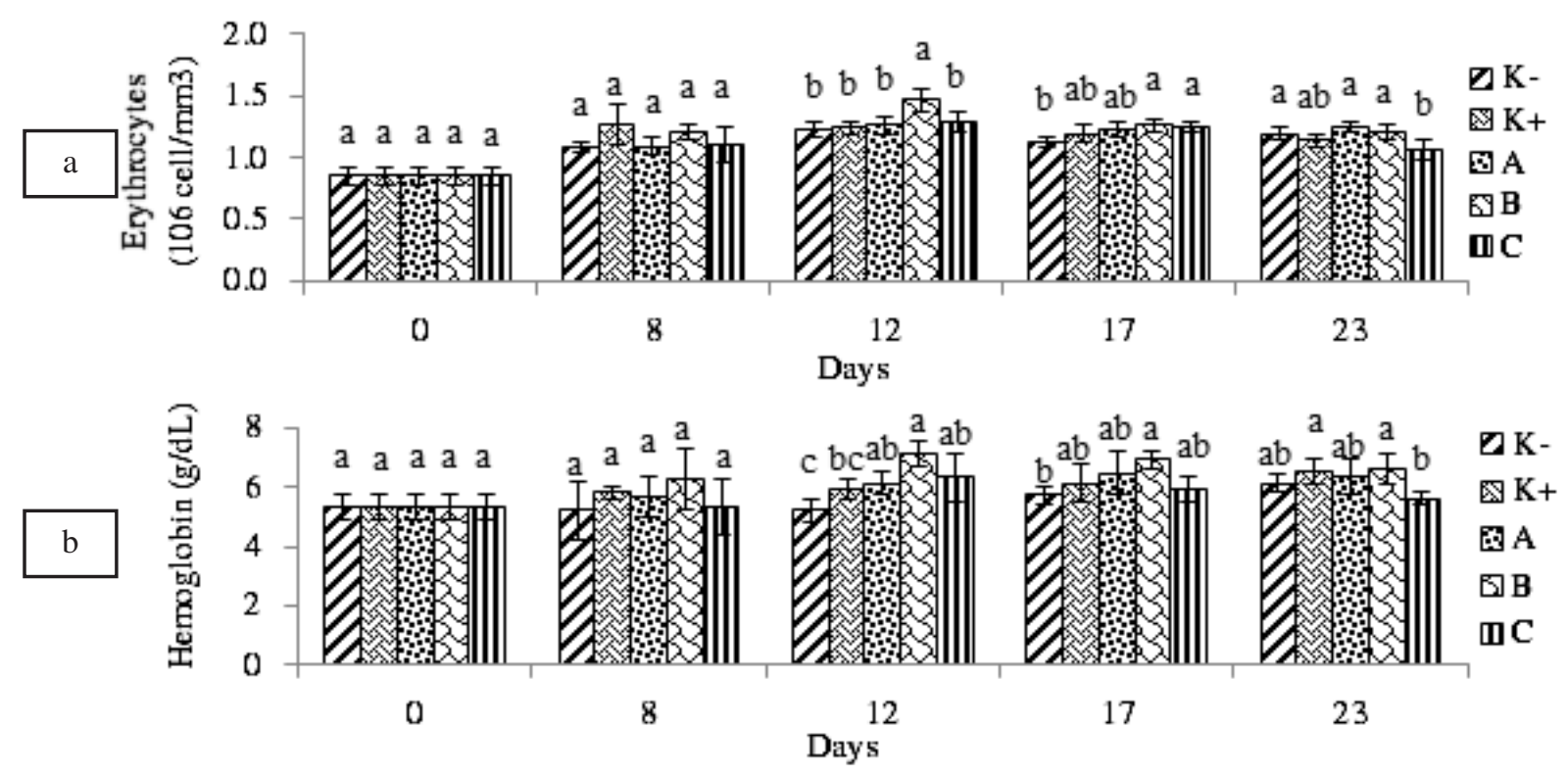

Figure 2. Total erythrocytes (a) and hemoglobin (b) of test fish both before (H0) and after (D8, D12, D17, and D23) challenge test with A. hydrophila. Different letters on each bar showed statistical differences (Duncan's multiple-range test; $\mathrm{P}<0.05)$. Without banana stem juice immersion and challenge test $(\mathrm{K}-)$; challenge test without banana stem juice immersion $(\mathrm{K}+)$; ambon banana stem juice immersion at concentrations of $5 \mathrm{~mL} / \mathrm{L}(\mathrm{A}) ; 13$ $\mathrm{mL} / \mathrm{L}(\mathrm{B}) ; 21 \mathrm{~mL} / \mathrm{L}(\mathrm{C})$ with challenge test.

that functions as antiseptic, antibacterial, and immuno-stimulator as well. Supporting results were provided by Lidiawati (2014), who demonstrated that the immersion of catfish in ambon banana stem extract can increase survival rate up to $83.33 \%$ compared to control treatments (just 30\%). A difference was observed in the survival rate post-challenge test in treatment $\mathrm{C}$, whose survival was lower than that of treatment A. That was believed to be a result of the increased concentration (ambon banana stem juice), which could cause the saponin active compound content to lower the immune system, leading to fish not being able to resist against pathogenic infection. According to Lukistyowati (2011), saponin enters the blood vessels and bind hemoglobin, causing blood deficiency that can lead to death.

A high survival rate is influenced by a good immune system of the fish, which is the defense system of the fish itself against pathogens. The mentioned system can be monitored by observing blood profile picture through parameters such as erythrocytes, hemoglobin level, total leukocytes, phagocytic activity, and lysozyme activity. Based on the observation results, total erythrocytes levels increased in all the treatments postchallenge test with $A$. hydrophila bacterium, ranging between $1.07 \times 10^{6} \mathrm{cell} / \mathrm{mm}^{3}$ and $1.47 \times 10^{6}$ cell $/ \mathrm{mm}^{3}$ compared to pre-challenge test results. The mentioned increment was still within the normal range and in accordance with Alamanda et al. (2007) research, who stated that the normal erythrocytes level of catfish ranges between $1.0 \times 10^{6} \mathrm{cell} / \mathrm{mm}^{3}$ and $3.0 \times 10^{6} \mathrm{cell} / \mathrm{mm}^{3}$. The increase in erythrocytes level was believed to be a consequence of the stress condition of the fish, which was due to the presence of pathogens in the fish body post bacterial infection. According to Mones (2008), a high erythrocytes level in blood is caused by the stress condition of the fish. In addition, Purwanti et al. (2014) reported that the higher the erythrocytes level, the bigger the hemoglobin level is. According to the statement above, hemoglobin level in blood increased postchallenge test, ranging between $5.6 \pm 0.2 \mathrm{~g} / \mathrm{dL}$ and $7.1 \pm 0.42 \mathrm{~g} / \mathrm{dL}$.

The leukocyte is a blood component that functions as a non-specific defense system that locates pathogens through a process called phagocytosis (Sukenda et al., 2008). Based on post-challenge test observation results, the total leukocytes in all the treatments experienced increments on day 12 , which was quite significant in treatment $\mathrm{B}$, being $10.7 \times 10^{4} \mathrm{cell} / \mathrm{mm}^{3}$. Increments in leukocytes levels were believed to be a result of the banana stem juice concentration of $13 \mathrm{~mL} / \mathrm{L}$ that was able to stimulate the nonspecific defense system of the fish body in order to quickly phagocytize extraneous cells when the body faces pathogenic attacks. Immersion using ambon banana stem juice can increase the leukocytes level in fish blood during pathogenic 

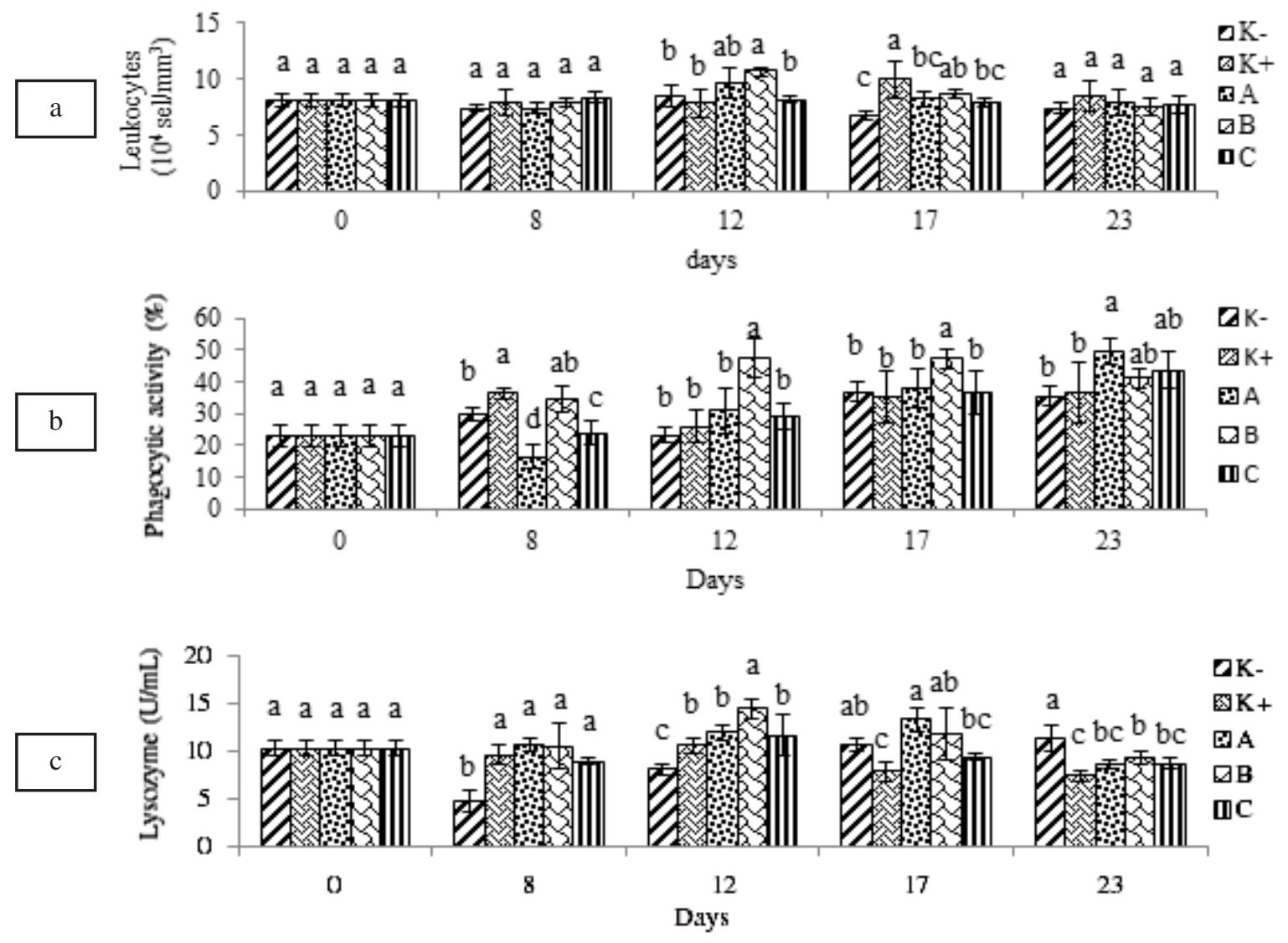

Figure 3. Total leukocytes (a); phagocytic activity (b); lysozyme activity (c) of test fish, fish both before (H0) and after (D8, D12, D17, and D23) challenge test with A. hydrophila. Different letters on each bar showed statistical differences (Duncan's multiple-range test; $\mathrm{P}<0.05)$. Without banana stem juice immersion and challenge test $(\mathrm{K}-$ ); challenge test without banana stem juice immersion $(\mathrm{K}+)$; ambon bana stem juice immersion at concentrations of $5 \mathrm{~mL} / \mathrm{L}(\mathrm{A}) ; 13 \mathrm{~mL} / \mathrm{L}(\mathrm{B}) ; 21 \mathrm{~mL} / \mathrm{L}(\mathrm{C})$ with challenge test.

infection since it contains flavonoids. Similar results were observed in a research conducted by Lukistyowati (2012), which results demonstrated that flavonoids (Sambiloto leaves) can increase leukocytes levels. According to Galina et al. (2009), an immune-stimulatory activity of flavonoids compound occurred through the stimulation of cytokine inter leukin-2 (IL-2) so that immunoglobulin-G (Ig) formation increases. However, reductions in the total leukocytes levels post-challenge test were observed on day 17 and day 23 , which were believed to be consequences of a reduction in blood vessels leukocytes that headed to the infected area of the body. That case above was in line with Nuryati et al. (2010) finding. In accordance with the total leukocytes, phagocytic activity in treatment B post-challenge test also experienced an increase that was significant compared to that of pre-challenge test i.e. $47.33 \pm 3.06 \%$. That was in accordance with Lukistyowati and Kurniasih (2011) finding, demonstrating that leukocytes possess the ability to phagocytize bacteria in defending the body against pathogenic attacks, leading to similarities between leukocytes level and phagocytic activity. Treatment B had the highest lysozyme activity $(14.44 \pm 1.02 \mathrm{U} / \mathrm{mL})$ that significantly differed compared to other treatments $(\mathrm{P}<0.05 \%)$. This showed that a high immune response ability of catfish (Sangkuriang strain) that was given ambon banana stem juice, at a concentration of $13 \mathrm{~mL} / \mathrm{L}$, against $A$. hydrophila bacteria.

The disease caused by $A$. hydrophila bacterium can result in massive death. Due to that, knowledge on symptoms of fish infected by A. hydrophila bacterium is of capital importance in both effectively handling and increasing the survival rate of the infected fish. Clinical symptoms of catfish post-challenge test with A. hydrophila bacterium included a reduction in appetite, swimming at the water surface, irregular movement, changes in body color, hemorrhage on the fish body, abdominal dropsy, and sores or ulcers on injection points. Clinical symptoms observations on day one revealed the presence of growing ulcers on the fish body, which, however, started to get smaller on day 4 post-challenge test. The ulcers commenced being 

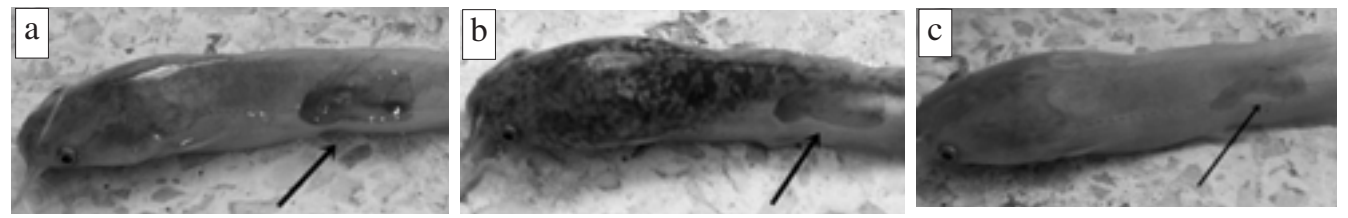

Figure 4. Catfish in treatment $\mathrm{K}+$ post-challenge test with A. hydrophila bacteria on day 1 (a); day 4 (b); day 9(c).
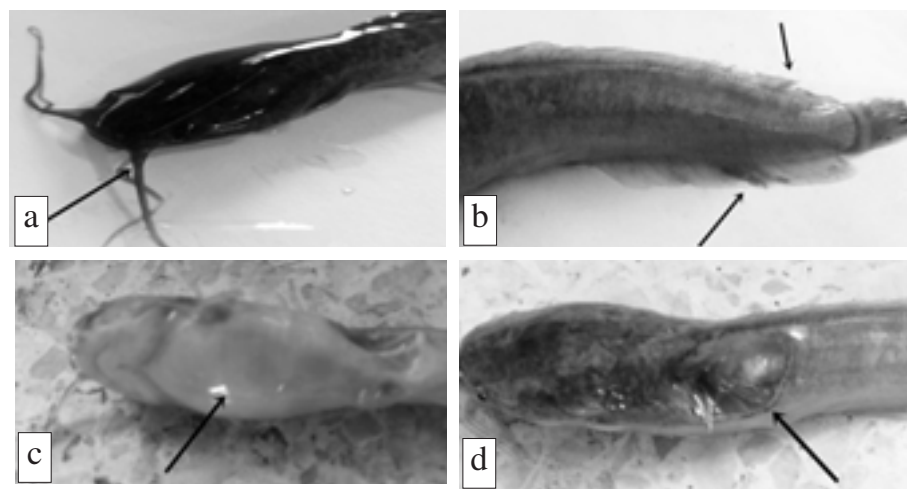

Figure 5. Clinical symptoms of morphological changes in catfish Clarias gariepinus post-challenge test with $A$. hydrophila bacteria (a) hemorraghe; (b) gizzled tail fin; presence of red spot (c) abdominal dropsy; (d) sores or ulcers on injection points.

Table 2. Average water quality parameters measured on a daily basis in each treatment during the research period

\begin{tabular}{lccccc}
\hline \multirow{2}{*}{ Treatments } & \multicolumn{5}{c}{ Parameters } \\
\cline { 2 - 6 } & $\begin{array}{c}\text { Temperature } \\
\left({ }^{\circ} \mathrm{C}\right)\end{array}$ & $\mathrm{pH}$ & $\begin{array}{c}\mathrm{DO} \\
(\mathrm{mg} / \mathrm{L})\end{array}$ & $\begin{array}{c}\text { TAN } \\
(\mathrm{mg} / \mathrm{L})\end{array}$ & Ammonia $(\mathrm{mg} / \mathrm{L})$ \\
\hline Negative control (K-) & $31-33$ & $5.4-7.0$ & $6.1-7.1$ & $0.230-0.760$ & $0.001-0.005$ \\
Positive control (K+) & $30-32$ & $5.4-6.9$ & $6.0-7.0$ & $0.256-0.751$ & $0.001-0.002$ \\
Treatment A & $31-33$ & $5.2-7.0$ & $5.0-7.3$ & $0.118-0.742$ & 0.001 \\
Treatment B & $30-32$ & $5.3-6.8$ & $5.2-7.4$ & $0.157-0.684$ & $0.001-0.002$ \\
Treament C & $31-33$ & $5.2-6.6$ & $5.0-7.2$ & $0.212-0.823$ & $0.001-0.002$ \\
INS (2000) & $25-30$ & $6.5-8.5$ & $\geq 4$ & $\leq 1$ & $\leq 0.01$ \\
\hline
\end{tabular}

Description: Immersion treaments with squeezed ambon banana stem juice at different concentrations i.e. $5 \mathrm{~mL} / \mathrm{L}$ (treatment A), $13 \mathrm{~mL} / \mathrm{L}$ (treatment B), and $21 \mathrm{~mL} / \mathrm{L}$ (treatment $\mathrm{C}$ ).

covered on day 9 post injection. The high number of ulcers on the first day post-challenge test was suspected to be a result of the ability of $A$. hydrophila bacterium to quickly develop within the 24 hours post injection. Pane (2013) stated that negative Gram bacteria enter the fish body to deep tissues by mean of a flagellum that allows the bacteria to move, leading to a very quick spread. Consequently, immersion using ambon banana stem juice can inhibit the development of bacteria since it contains flavonoids. Krisnata et al. (2014) stated that flavonoid is an active compound that functions as both antibacterial and antifungals. According to Kusdarwati et al. (2010), antibacterial compound functions by breaking the cell membrane, leading to a stop of both ion and compound transportations to the bacterial cell. That constraint in transportation will result in a decrease in bacteria nutrition that is needed for growth.

Feed conversion ratio is a ratio that displays the amount of feed required to reach a given weight. The results of the present study showed that all the treatments, subjected to the challenge test with A. hydrophila, had different feed conversion ratios. Treatment $\mathrm{B}$ had a feed conversion ratio of $1.08 \pm 0.04$ that was lower than those of treatment $\mathrm{A}$ (1.32 \pm 0.23$), \mathrm{C}(1.22 \pm 0.04)$, and $\mathrm{K}+(1.36 \pm 0.11)$, indicating that tested fish in treatment B could benefit from the given feed. 


\section{CONCLUSION}

Immersion using ambon banana stem juice at a concentration of $13 \mathrm{~mL} / \mathrm{L}$ (for 30 minutes) over a period of 7 days can effectively increase immunity, leading to a high survival rate of catfish against $A$. hydrophila infection.

\section{REFERENCES}

Alamanda EI, Handajani NS, Budiharjo A. 2007. The use of hematology method and blood endoparasite observation for determining catfish Clarias gariepinus health in fishery Mangkubumen, Boyolali. Biodeversitas 8: 34-38.

Galina J, Yin G, Ardo L, Jeney Z. 2009. The use of Immunostimulating Herb in Fish. An Overview of research. Fish Physiology and Biochemistry 35: 669-676.

Krisnata BA, Rizka Y, Mulawarmanti D. 2014. Daya hambat ekstrak daun mangrove Avicennia marina terhadap pertumbuhan bakteri Mixed periodontopatogen. Jurnal Kedokteran Gigi 8: 22-25.

Kusdarwati R, Ludira S, Akhmad TM. 2010. Antibacterial effort of adas fruit Foeniculum vulgare extract on Micrococcus luteus bacterial by in vitro. Jurnal Ilmiah Perikanan dan Kelautan 2: 32-41.

Lidiawati E. 2014. Immersion effectiveness of catfish Clarias sp. in banana stem extract Musa paradisiaca which was infected by Aeromonas hydrophila [Mini Thesis]. Bogor: Institut Pertanian Bogor.

Loganayaki N, Rajendrakumaran D, Manian S. 2010. Antioxidant capacity and phenolic content of different solvent extracts from banana Musa paradisiaca and mustai Rivea hypocrateriformis. Food Science and Biotechnology 19: 1251-1258.

Lukistyowati I, Kurniasih. 2011. Kelangsungan hidup ikan mas Cyprinus carpio L. yang diberi pakan ekstrak bawang putih Allium sativum dan diinfeksi Aeromonas hydrophila. Jurnal Perikanan dan Kelautan 16: 144-160.

Lukistyowati I. 2012. Studi efektivitas sambiloto Andrographis paniculata Ness untuk mencegah penyakit edwardsiellosis pada Ikan Patin Pangasius hypopthalmus. Berkala perikanan Terubuk 40: 56-74.

Maqsood S, Samoon MH, Singh P. 2009. Immunomodulatory and growth promoting effect of dietary levamisole in Cyprinus carpio fingerlings against the challenge of Aeromonas hydrophila. Turkish Journal of Fisheries and Aquatic Sciences 9: 111-120.

Mones RA. 2008. Gambaran darah pada ikan mas Cyprinus carpio strain majalaya yang berasal dari daerah Ciampea Bogor [Mini Thesis]. Bogor: Institut Pertanian Bogor.

Nuryati S, Maswan NA, Alimuddin, Sukenda, Sumantadinata K, Pasaribu FH, Soejoedono RD, Santika A. 2010. Hematology of common carp following DNA vaccination and koi herpesvirus challenge test. Jurnal Akuakultur Indonesia 9: 9-15.

Pane EA. 2013. Uji aktivitas senyawa antioksidan dari ekstrak metanol kulit pisang raja Musa paradisiaca sapientum. Jurnal Valensi 3: 7681.

Prasetyo BF, Wientarsih I, Priosoeryanto BP. 2010. Aktivitas sediaan gel ekstrak batang pohon pisang ambon dalam proses penyembuhan luka pada mencit. Jurnal Veteriner 11: 70-73.

Purwanti SC, Suminto, Sudaryono A. 2014. The description of blood profile catfish Clarias gariepinus that is fed with a combination of artificial feed and earthworm Lumbricus rubellus. Journal of Aquaculture Management and Technology 3: 53-60.

Rairakhwada, Dina, Pal AK, Bhathena ZP, Sahu NP, Jha A, Mukherjee SC. 2007. Dietary microbial levan enhances cellular non-specific immunity and survival of common carp Cyprinus carpio juveniles. Fish and Shellfish Immunology 22: 477-486.

[SNI] Standar Nasional Indonesia. 2000. Produksi benih ikan lele dumbo Clarias gariepinus $\mathrm{x}$ C. Fuscus kelas benih sebar. Indonesia (ID): BSN.

Sukenda, Jamal L, Wahjuningrum D, Hasan A. 2008. Use of chitosan to prevent Aeromonas hydrophila infection on catfish Clarias sp. Jurnal Akuakultur Indonesia 7: 159-169. 